\title{
Changes in activities of superoxide dismutase and lipid peroxide in corpus luteum during pregnancy in rats
}

\author{
N. Sugino ${ }^{1,2}$, Y. Nakamura ${ }^{2}$, O. Takeda $^{2}$, M. Ishimatsu ${ }^{2}$ and \\ H. Kato ${ }^{2 *}$ \\ ${ }^{1}$ Department of Obstetrics and Gynecology, Sanyo Central Hospital, Sanyo, Asa, 757 Japan; and \\ ${ }^{2}$ Department of Obstetrics and Gynecology, Yamaguchi University School of Medicine, \\ 1144 Kogushi, Ube, 755 Japan
}

\begin{abstract}
Activities of superoxide dismutase (SOD) and lipid peroxide (LPO) were studied in corpora lutea of pregnant rats. SOD activities, both $\mathrm{Mn}$-SOD and $\mathrm{Cu}, \mathrm{Zn}-\mathrm{SOD}$, gradually increased in the corpora lutea until day 15 of pregnancy and decreased thereafter until day 21 of pregnancy, in a similar manner to serum progesterone concentration. LPO activities remained low until day 15 of pregnancy, but increased rapidly after day 15 to day 21 of pregnancy. Incubation of the dispersed luteal cells from day 15 of pregnancy in vitro showed that $\mathrm{FeSO}_{4}$ and ascorbic acid, which induce lipid peroxidation, significantly inhibited progesterone secretion. The inhibitory effects of $\mathrm{FeSO}_{4}$ and ascorbic acid were blocked by the simultaneous addition of $\alpha$-tocopherol. These results suggest important roles for SOD and LPO in regulating luteal function during pregnancy.
\end{abstract}

\section{Introduction}

It is well known that reactive oxygen species and their product lipid peroxide (LPO) damage the cell membrane (Tappel, 1973; Mead, 1976; Harman, 1982; Fridovich, 1983; O'Brien, 1984; Slater, 1984), by cross-linking in proteins and lipids, and by formation of the gel-phase lipid (Pauls and Thompson, 1980). Gatzuli et al. (1991) reported the anti-gonadotrophic and anti-steroidogenic actions of superoxide radical in rat luteal cells. Sawada and Carlson (1989) reported that the production of superoxide radical was increased in the plasma membrane of the corpus luteum during the regression phase in pseudopregnant rats. Lipid peroxidation, which is induced by superoxide radicals (Hochstein and Jain, 1981), also increases during the regression of the corpora lutea in pseudopregnant rats (Sawada and Carlson, 1985). Furthermore, luteal contents of superoxide dismutase (SOD), a scavenger of the superoxide radical, change during the ovulatory cycle in rats (Laloraya et al., 1989) and humans (Shiotani et al., 1991), or are even increased by luteinizing hormone in pseudopregnant rats (Laloraya et al., 1988). It is therefore likely that superoxide radicals and their scavenging system play important roles in generating the luteal function. The present study was undertaken to investigate the involvement of SOD and LPO in the regulation of luteal function during pregnancy in rats.

\section{Materials and Methods}

\section{Animals}

Sprague-Dawley rats, weighing $220-270 \mathrm{~g}$, were housed under controlled conditions (lights on from 05:00 to 19:00 h)

${ }^{*}$ Correspondence.

Received 10 March 1992. with free access to standard rat chow and water. Pro-oestrous rats were housed with males overnight, and day $I$ of pregnancy was the day on which spermatozoa were found in the vaginal smear.

\section{Treatments}

Operations were carried out between 16:00 and 18:00 h on days $1,7,12,15,17,19$ or 21 of pregnancy. Rats were laparotomized under ether anaesthesia and blood samples were obtained from the portal vein. The ovaries were perfused with saline via the portal vein while blood samples were taken from the inferior vena cava. The ovaries were removed, and the corpora lutea were dissected and cleaned of adhering tissue in a watch glass. For assay of SOD, corpora lutea were homogenized with Tris $\mathrm{HCl}$ buffer $\left(0.1 \mathrm{~mol} \mathrm{l}^{-1}, \mathrm{pH} 7.4\right)$, centrifuged at $800 \mathrm{~g}$ for $10 \mathrm{~min}$ at $4{ }^{\circ} \mathrm{C}$ and the supernatant was stored at $-70^{\circ} \mathrm{C}$. For assay of LPO, corpora lutea were homogenized with $1.15 \% \mathrm{KCl}$ and the supernatant was stored at $-70^{\circ} \mathrm{C}$. Serum samples were stored at $-20^{\circ} \mathrm{C}$ for progesterone assay.

\section{Cell preparation for incubation in vitro}

On day 15 of pregnancy, ovaries were removed under light ether anaesthesia and the corpora lutea were dissected free from the ovary into the medium (Dulbecco's Modified Eagle's Medium: HAM's nutrient mixture F12 $1: 1$, containing $30 \mu \mathrm{g}$ glutamine $\mathrm{ml}^{-1}$ ). The corpora lutea were minced and incubated in the medium containing $0.125 \%$ collagenase (type I, Sigma Chemical Co., St Louis, MO) and hyaluronidase $0.125 \%$ (type $\mathrm{V}$, Sigma Chemical Co.) for $40 \mathrm{~min}$ at $37^{\circ} \mathrm{C}$ under an atmosphere of $95 \% \mathrm{O}_{2}: 5 \% \mathrm{CO}_{2}$ in a shaking water bath. The medium 
was replaced with fresh medium containing $0.25 \%$ trypsin (DIFCO laboratories, Detroit, MI) and incubation was continued for $40 \mathrm{~min}$ under the same atmosphere. After incubation, the tissue was placed in the fresh medium containing $0.1 \%$ trypsin inhibitor (type II-S, Sigma Chemical Co.), and dispersed to cells by flushing through a Pasteur pipette. The cell suspension was filtered through a nylon mesh (150X-T2), and spun at $800 \mathrm{~g}$ for $5 \mathrm{~min}$ at $22^{\circ} \mathrm{C}$. The cells were suspended in the culture medium, containing $10 \%$ fetal calf serum (Bioproducts Inc., Walkersville, MD), $50 \mathrm{U}$ penicillin $\mathrm{ml}^{-1}$ and $100 \mu \mathrm{g}$ streptomycin $\mathrm{ml}^{-1}$. The cell number and viability were tested by the trypan blue exclusion method, and the number of cells was adjusted to $1 \times 10^{5}$ viable cells $\mathrm{ml}^{-1}$. The cell suspension $(100 \mu \mathrm{l})$ was distributed into each well of a Falcon 96-well tissue culture plate (Nippon Becton Dickinson Co. Ltd, Tokyo) which contained $\mathrm{FeSO}_{4}\left(40 \mu \mathrm{mol} \mathrm{^{-1 }}\right)$, ascorbic acid $(100,200$ or $400 \mu \mathrm{mol} \mathrm{l}^{-1}$ ) (Nakarai Co. Ltd, Tokyo), and hCG $\left(0.2 \mathrm{U} \mathrm{ml}^{-1}\right.$ ) (Sigma Chemical Co.) in $100 \mu \mathrm{l}$ of the medium. The incubation was continued for $2 \mathrm{~h}$ at $37^{\circ} \mathrm{C}$ under an atmosphere of $95 \%$ air: $5 \% \mathrm{CO}_{2}$. At the end of incubation, the culture plates were centrifuged at $800 \mathrm{~g}$ for $5 \mathrm{~min}$, and the supernatant was stored at $-20^{\circ} \mathrm{C}$ for progesterone assay. The specificity of $\mathrm{FeSO}_{4}-$ ascorbic acid reaction to induce lipid peroxidation was tested by adding $100 \mu \mathrm{l}$ of DL- $\alpha$-tocopherol (50 or $100 \mu \mathrm{mol} \mathrm{^{-1 }}$ ) (Nakarai), an inhibitor of lipid peroxidation, to several wells containing $40 \mu \mathrm{mol} \mathrm{FeSO}{ }_{4} 1^{-1}, 100 \mu \mathrm{mol}$ ascorbic acid $1^{-1}$ and $1 \times 10^{4}$ cells.

\section{Determination of SOD activity}

Total SOD activity was measured by the nitrite method reported by Oyanagi (1984), using the following reagents: (1) buffer solution: $60.6 \mathrm{mmol} \mathrm{Na}_{2} \mathrm{~B}_{4} \mathrm{O}_{7} \cdot 10 \mathrm{H}_{2} \mathrm{O} \mathrm{l}^{-1}$ and $86.8 \mathrm{mmol} \mathrm{KH}_{2} \mathrm{PO}_{4} \mathrm{l}^{-1}$ (pH 8.2); (2) reagent $\mathrm{A}: 2.0 \mathrm{mmol}$ hypoxanthine $\mathrm{I}^{-1}(\mathrm{pH}$ 8.2) (Nakarai Co. Ltd) dissolved in buffer solution; (3) reagent $\mathrm{B}: 10.9 \mathrm{mmol}$ hydroxylamine $\mathrm{HCl} 1^{-1}$ (Nakarai Co. Ltd) and $8.8 \mathrm{mmol}$ hydroxylamine-O-sulfonic acid $1^{-1}$ (Merck-Schuchardt, München); (4) enzyme reagent: $1.33 \times 10^{-2} \mathrm{U}$ xanthine oxidase $\mathrm{ml}^{-1}$ (Boehringer Mannheim BmbH Biochemica, Germany) and $0.8 \mathrm{mmol}$ EDTA $\cdot 2 \mathrm{Na}^{-1}$ (Sigma Chemical $\mathrm{Co}$.) dissolved in buffer solution; (5) colouring reagent: $33.2 \mu \mathrm{mol} \mathrm{N}$-I-naphthylethylenediamine $1^{-1}$ (Nakarai Co. Ltd) and $2.6 \mathrm{mmol}$ sulfonic acid $\mathrm{l}^{-1}$ (Nakarai Co. Ltd) and $25 \%$ acetic acid. Reagent $A(0.1 \mathrm{ml})$, reagent $B(0.1 \mathrm{ml})$ and $0.1 \mathrm{ml}$ of the test sample were added to $0.5 \mathrm{ml}$ distilled water. After preincubation for $5 \mathrm{~min}$ at $37^{\circ} \mathrm{C}, 0.2 \mathrm{ml}$ of enzyme reagent was added, and the mixture was incubated for $30 \mathrm{~min}$ at $37^{\circ} \mathrm{C}$, followed by the addition of $2.0 \mathrm{ml}$ of colouring reagent. The final mixture was left for $30 \mathrm{~min}$ at room temperature and optical absorption was then measured at $550 \mathrm{~nm}$. The Mn-SOD assay was performed in exactly the same way as the assay for

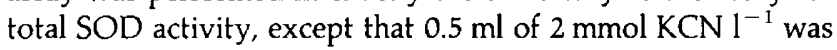
added instead of $0.5 \mathrm{ml}$ distilled water. Usually, dose-response curves with serial dilutions of the samples were linear between 2 and $40 \mu \mathrm{g}$ protein per tube. The amount of protein required for $50 \%$ inhibition was defined as one unit (Nitrite Unit; NU) of SOD activity. All data were expressed in Nitrite Unit (NU) of SOD activity per mg protein. Protein concentration was measured by the method reported by Lowry et al. (1951), $\mathrm{Cu}, \mathrm{Zn}$-SOD activity was determined by subtracting Mn-SOD activity from the total SOD activity. The intra- and interassay coefficients of variation were $3.8 \%$ and $9.6 \%$ for the total SOD assay, and $4.7 \%$ and $6.4 \%$ for the Mn-SOD assay, respectively.

\section{Determination of LPO activity}

Concentrations of LPO in the corpus luteum were measured by the thiobarbituric acid method of Ohkawa et al. (1979). Dose-response curves with serial dilutions of the sample were linear between 5 and $20 \mu \mathrm{g}$ protein per tube. The results were expressed as $\mathrm{nmol}$ of malondialdehyde (MDA) per $\mathrm{g}$ wet weight of tissue.

\section{Progesterone assay}

Serum progesterone concentrations were determined by the specific radioimmunoassay reported by Kato et al. (1982). The sensitivity of the assay was $100 \mathrm{pg}$ per tube, and the intraand interassay coefficients of variation were $7 \%$ and $14.4 \%$, respectively.

\section{Statistical analysis}

Data were analysed by analysis of variance and the new Duncan's multiple range test. Differences were considered to be significant if $P<0.05$.

\section{Results}

Total SOD and Mn-SOD activities, as well as $\mathrm{Cu}, \mathrm{Zn}-\mathrm{SOD}$ activity, changed in parallel during pregnancy; activities increased at day 12 of pregnancy and gradually decreased thereafter (Fig. 1).

A positive correlation was found between serum progesterone concentrations and total SOD activity $(r=0.63, P<0.01)$ (Fig. 2). In contrast, LPO concentrations increased rapidly from day 15 to day 21 of pregnancy. LPO activities showed negative correlations with serum progesterone concentrations $(r=-0.74, P<0.01)$, or total SOD activity $(r=-0.46$, $P<0.05)$.

Progesterone production of dispersed luteal cells was significantly $(P<0.05)$ inhibited by $\mathrm{FeSO}_{4}$ and ascorbic acid in a dose dependent manner (Fig. 3). Progesterone production in the absence of hCG was not significantly inhibited by $\mathrm{FeSO}_{4}$ and ascorbic acid (data are not shown). The inhibitory effect of $\mathrm{FeSO}_{4}$ plus ascorbic acid on progesterone secretion was blocked by the simultaneous addition of $\alpha$-tocopherol (Fig. 4).

\section{Discussion}

This study shows that the marked decrease in serum progesterone concentration after day 15 of pregnancy coincided with the rapid increase in lipid peroxide activity in the corpus luteum. These data are consistent with the previous findings that superoxide radicals and lipid peroxidation increase during the regressing phase of corpus luteum (Sawada and Carlson, 1985, 


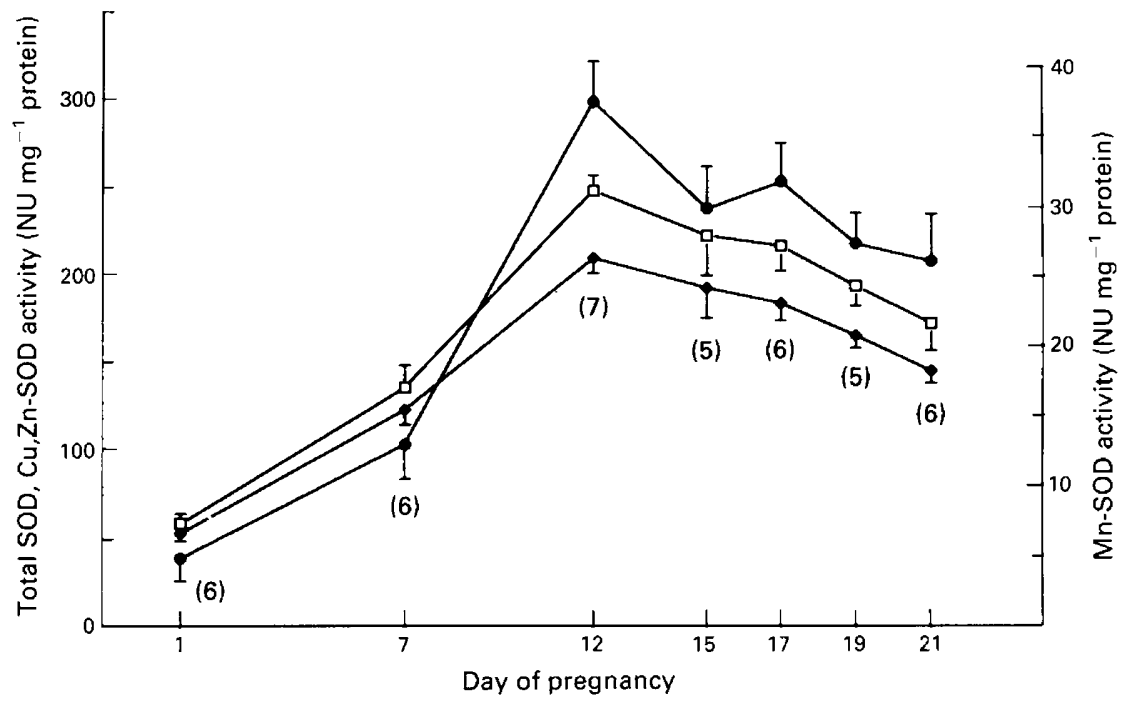

Fig. 1. Changes in $\mathrm{Cu}, \mathrm{Zn}-\mathrm{SOD}(\bullet), \mathrm{Mn}-\mathrm{SOD}(\bigcirc)$ and total SOD $(\square)$ activities in the corpus luteum of rats during pregnancy. Values are means \pm SEM for the number of animals given in parentheses. NU: nitrate unit.

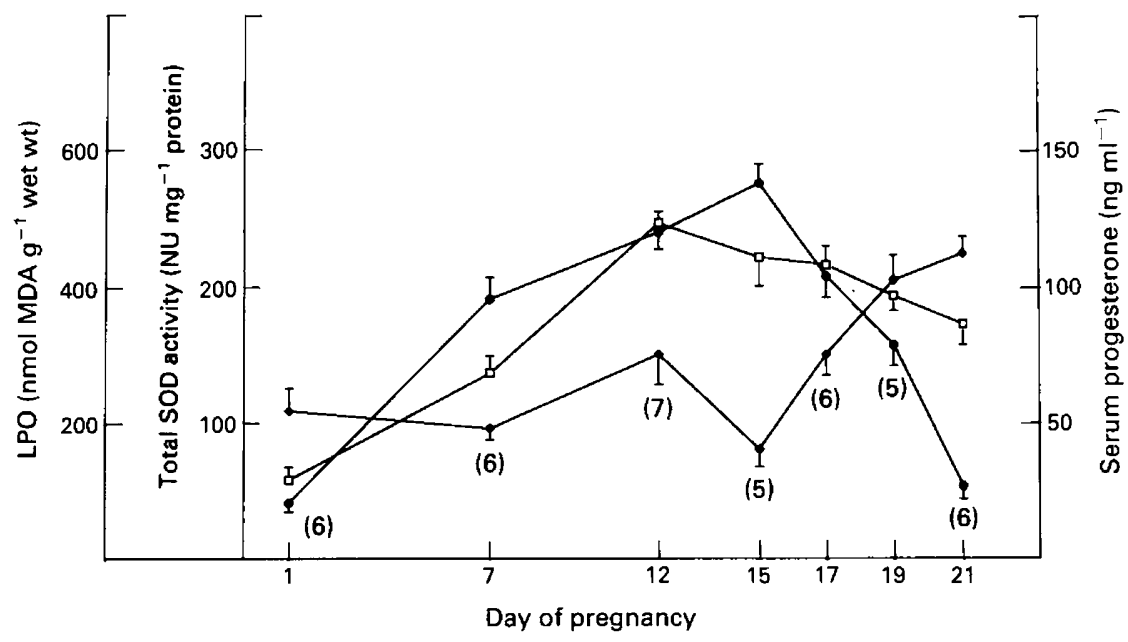

Fig. 2. Changes in serum progesterone concentration ( $)$, total SOD activity ( $\square$ ), and LPO concentrations $(\bullet)$ in the corpus luteum of rats during pregnancy. Values are means \pm SEM for the number of animals given in parentheses. NU: nitrate unit.

1989), and inhibit luteal function (Gatzuli et al., 1991). This is also confirmed by the present data showing that $\mathrm{FeSO}_{4}$ and ascorbic acid inhibited the progesterone production of the dispersed luteal cells. Lipid peroxidation, induced by free radicals (Hochstein and Jain, 1981), caused membrane damage such as changing membrane fluidity (Pauls and Thompson, 1980). Behrman and Preston (1989) reported that hydrogen peroxide caused rapid inhibition of luteinizing hormone-stimulated cAMP accumulation in the membrane of the rat corpus luteum that resulted in the decrease of progesterone production. Behrman and Aten (1991) further demonstrated that peroxide inhibited the luteinizing hormone-dependent component of steroidogenesis, which agrees with our present data showing that $\mathrm{FeSO}_{4}$ plus ascorbic acid inhibited the hCG-stimulated production of progesterone, but did not affect the basal production of progesterone in the absence of hCG. Anti-gonadotrophic actions of hydrogen peroxide were also reported in rat ovarian cells (Margolin et al., 1990). Since it has been clearly demonstrated that hydrogen peroxide blocked the transport of cholesterol from cytosol to mitochondria (Behrman and Aten, 1991), it would be reasonable to suppose that the free radical system plays a crucial role in the luteolytic process, probably by inhibiting the production of progesterone.

It is unclear how lipid peroxidation is increased after day 15 of pregnancy in rats. It is interesting to note that lipid peroxidation occurs during the ageing process of cells (Tappel, 1973). SOD activity decreases with age in rats (Reiss and Gershon, 1976), and the auto-oxidation of polyunsaturated fatty acids, which stimulates the production of lipid peroxides (Tappel, 1980; Harman, 1981), increases during the ageing process 


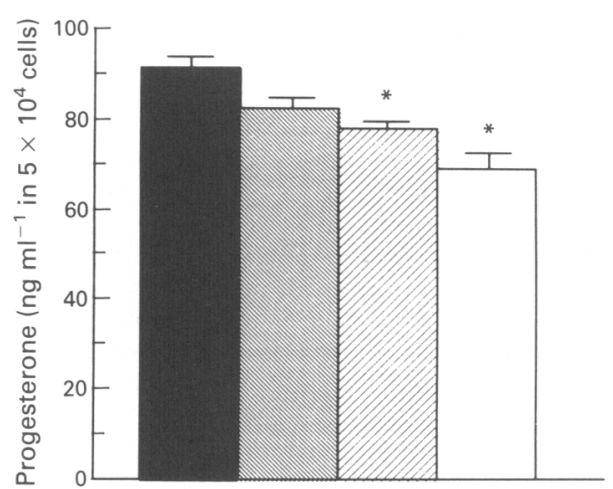

Fig. 3. Effects of $\mathrm{FeSO}_{4}$ and ascorbic acid on progesterone production from rat luteal cells. (Control: $\square_{\text {; }} \mathrm{FeSO}_{4}$ plus $50 \mu \mathrm{mol}$ ascorbic acid $\mathrm{l}^{-1}: \mathbb{N} ; \mathrm{FeSO}_{4}$ plus $100 \mu \mathrm{mol}$ ascorbic acid $\mathrm{l}^{-1}$ : 团; $\mathrm{FeSO}_{4}$ plus $200 \mu \mathrm{mol}$ ascorbic acid $\mathrm{l}^{-1}: \square$ ). Each bar represents the mean \pm SEM of five incubations from one of two similar experiments. ${ }^{*} P<0.05$ compared with the control group (new Duncan's multiple range test).

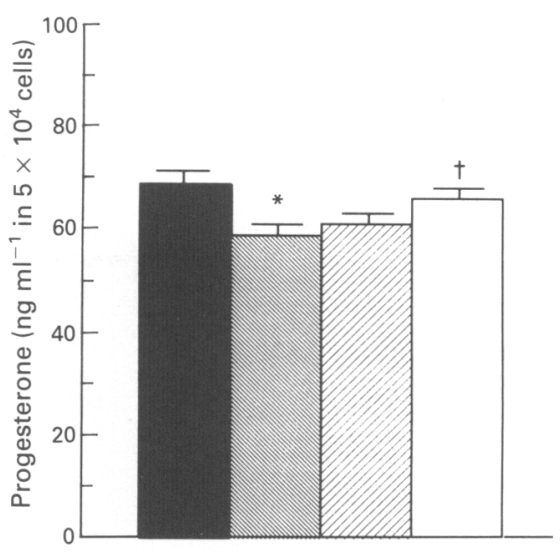

Fig. 4. Effects of $\alpha$-tocopherol on progesterone production from luteal cells. (Control: $\mathbf{\square} ; \mathrm{FeSO}_{4}$ plus ascorbic acid: $\mathbf{N} ; \mathrm{FeSO}_{4}$ plus ascorbic acid plus $25 \mu \mathrm{mol} \alpha$-tocopherol $\mathrm{l}^{-1}: \oslash, \mathrm{FeSO}_{4}$ plus ascorbic acid plus $50 \mu \mathrm{mol} \alpha$-tocopherol $1^{-1}: \square$ ). Each bar represents the mean \pm SEM of six incubations from one of two similar experiments. ${ }^{*} P<0.01$ compared with the control group; $\uparrow P<0.01$ compared with $\mathrm{FeSO}_{4}$ plus ascorbic acid groups (new Duncan's multiple range test).

(Logani and Davies, 1980). Reduction of blood flow, one of the typical characteristics of ageing, occurs during regression of the corpus luteum (Pang and Behrman, 1979) and stimulates the conversion of xanthine dehydrogenase to xanthine oxidase which stimulates the production of superoxide radical and cell damage (McCord, 1985). Decreases in SOD and increases in lipid peroxides may be related to the ageing phenomena of the corpus luteum.

Although the involvement of prostaglandins in the luteolytic process has been clearly indicated (Rothchild, 1981), the initial trigger of prostaglandin synthesis at the beginning of luteolysis is unknown. There is some evidence that the production of superoxide radicals is stimulated by arachidonic acid (Clark et al., 1987) or prostaglandin $\mathrm{F}_{2 \alpha}$ (Sawada and Carlson, 1991; Aten et al., 1992), whereas superoxide radical also activates phospholipase $\mathrm{A}_{2}$ activity (Sawada and Carlson, 1991) or prostaglandin synthesis (Rahimtula and O'Brien, 1976; Hemler et al., 1979; Hemler and Lands, 1980; Band $e$ t al., 1981). Further studies are needed regarding the interrelation in the biosynthesis process between prostaglandins and superoxide.

The present data also showed that the change in SOD activity in the corpus luteum was parallel to that of serum progesterone concentrations, decreasing rapidly after day 15 of pregnancy (Fig. 2). SOD converts superoxide radical to hydrogen peroxide, which should certainly have luteolytic activity (Behrman and Preston, 1989). However, lipid peroxide remained low during mid-pregnancy and began to rise after day 15 of pregnancy. This may be due to the rapid conversion of hydrogen peroxide to $\mathrm{H}_{2} \mathrm{O}$. Hydrogen peroxide is converted to $\mathrm{H}_{2} \mathrm{O}$ by catalase and glutathione peroxidase, and glutathione peroxidase is increased by luteotrophins (Agrawal and Laloraya, 1977). Since placental luteotrophins are increased during midpregnancy in rats (Greenwald and Rothchild, 1968), it is likely that hydrogen peroxide is rapidly converted to $\mathrm{H}_{2} \mathrm{O}$ at about day 15 of pregnancy. Our previous findings that the luteal function in rats with one conceptus was influenced by environmental stress, for example ACTH or corticosterone treatments, much more than that in rats with full complements of conceptuses (Kato et al., 1988; Sugino et al., 1991) suggest that placental luteotrophins play a role in the regulation of the superoxide radical system in the corpus luteum.

This work was supported in part by Grant-in-Aid (03771100) from the Ministry of Education, Science and Culture, Japan.

\section{References}

Agrawal P and Laloraya MM (1977) Induction of peroxidase in corpora lutea of rat ovary by luteotropin Biochemical joumal 166 205-208

Aten RF, Duarte KM and Behrman HR (1992) Regulation of ovarian antioxidant vitamins, reduced glutathione, and lipid peroxidation by luteinizing hormone and prostaglandin $\mathrm{F}_{2 a}$ Biology of Reproduction 46 401-407

Band L, Nivez MP, Chansel D and Ardaillon R (1981) Stimulation by oxygen radicals of prostaglandin production by rat renal glomeruli Kidney International $20332-339$

Behrman HR and Aten RF (1991) Evidence that hydrogen peroxide blocks hormone-sensitive cholesterol transport into mitochondria of rat luteal cells Endocrinology 128 2958-2966

Behrman HR and Preston SL (1989) Luteolytic actions of peroxide in rat ovarian cells Endocrinology 129 2895-2900

Clark RA, Leidal KG, Pearson DW and Nauseef WM (1987) NADPH oxidase of human neutrophils Journal of Biological Chemistry $2624065-4074$

Fridovich I (1983) Superoxide radical: an endogenous toxicant Annual Reviews of Pharmacology and Toxicology 23 239-257

Gatzuli E, Alter RF and Behrman HR (1991) Inhibition of gonadotropin action and progesterone synthesis by xanthine oxidase in rat luteal cells Endocrinology 128 2253-2258

Greenwald GS and Rothchild I (1968) Formation and maintenance of corpus luteum in laboratory animals Journal of Animal Sciences 27 (Supplement 1) 27 139-161

Harman D (198I) The aging process Proceedings of the National Academy of Sciences USA 78 7124-7128

Harman D (1982) The free radical theory of aging. In Free Radicals in Biology Vol. 5 pp 255-275 Ed. WA Pryon. Academic Press, New York

Hemler ME and Lands WEM (1980) Evidence for a peroxide initiated free radical mechanism of prostaglandin biosynthesis Joumal of Biological Chemistry $\mathbf{2 5 5}$ $6253-6260$ 
Hemler ME, Cook HW and Lands WEM (1979) Prostaglandin biosynthesis can be triggered by lipid peroxides Archives of Biochemistry and Biophysics 193 $340-345$

Hochstein P and Jain SK (1981) Association of lipid peroxidation and polymerization of membrane proteins with erythrocyte aging Federation Proceedings 40 183-188

Kato H, Ueda K, Tsutsui H, Miyauchi F and Torigoe T (1982) Role of the non-gravid part of the uterus in the regulation of corpus luteum function in pregnant rats Endocrinology 111 2020-2024

Kato H, Nanjo K, Numa F, Nakamura $Y$, Ueda $K$, Inoguchi $H$ and Torigoe $T$ (1988) Inhibitory effects of adrenocorticotrophin or corticosterone on progesterone secretion during mid-pregnancy in rats Joumal of Reproduction and Fertility 83 867-872

Laloraya M, Kumar GP and Laloraya MM (1988) Changes in the levels of superoxide anion radical and superoxide dismutase during the estrous cycle of Rattus norvegicus and induction of superoxide dismutase in rat ovary by luteotropin Biochemical and Biophysical Research Communications 157 146-153

Laloraya M, Kumar GP and Laloraya MM (1989) Histochemical study of superoxide dismutase in the ovary of the rat during the oestrous cycle Joumat of Reproduction and Fertility $86583-587$

Logani MK and Davies RE (1980) Lipid oxidation: biologic effects and antioxidants - a review Lipids 15 485-495

Lowry OH, Rosebrough NJ, Farr AL and Randall RF (1951) Protein measurement with the Folin phenol reagent Joumal of Biological Chemistry 193 265-275

McCord JM (1985) Oxygen-derived free radicals in postischemic tissue injury New England Joumal of Medicine 312 159-163

Margolin Y, Aten RF and Behrman HR (1990) Antigonadotropic and antisteroidogenic actions of peroxide in rat granulosa cells Endocrinology $\mathbf{1 2 7}$ 245-250

Mead JF (1976) Free radical mechanisms of lipid damage and consequence for cellular membranes. In Free Radicals in Biology Vol. I pp 51-68 Ed. WA Pryor. Academic Press, New York

O'Brien PJ (1984) Multiple mechanisms of metabolic activation of aromatic amine carcinogens. In Free Radicals in Biology Vol. 6 pp 289-322 Ed. WA Pryor. Academic Press, New York
Ohkawa H, Onishi $\mathbf{N}$ and Yagi $\mathbf{K}$ (1979) Assay for lipid peroxides in animal tissue by thiobarbituric acid reaction Analytical Biochemistry 95 351-358

Oyanagi Y (1984) Reevaluation of assay methods and establishment of kit for superoxide dismutase activity Analytical Biochemistry 142 290-296

Pang CY and Behrman HR (1979) Relationship of luteal blood flow and corpus luteum function in pseudopregnant rats American Joumal of Physiology 237 E30-E34

Pauls KP and Thompson JE (1980) In vitro stimulation of senescence-related membrane damage by ozone-induced lipid peroxidation Nature 283 504-506

Rahimtula A and O'Brien PJ (1976) The possible involvement of singlet oxygen in prostaglandin biosynthesis Biochemical and Biophysical Research Communications $70893-899$

Reiss U and Gershon D (1976) Rat liver superoxide dismutase: purification and age related modifications European Journal of Biochemistry 63 617-623

Rothchild 1 (1981) The regulation of the mammalian corpus luteum Recent Progress in Hormone Research 37 183-298

Sawada M and Carlson JC (1985) Association of lipid peroxidation during luteal regression in the rat and natural aging in the rotifer Experimental Gerontology 20 179-186

Sawada M and Carlson JC (1989) Superoxide radical production in plasma membrane samples from regressing rat corpora lutea Canadian Journal of Physiology and Pharmacology 67 465-471

Sawada M and Carlson JC (1991) Rapid plasma membrane changes in superoxide radical formation, fluidity, and phospholipase $A_{2}$ activity in induction of luteolysis Endocrinology 128 2992-2998

Shiotani M, Noda Y, Narimoto K, Imai K, Mori T, Fujimoto K and Ogawa K (1991) Immunohistochemical localization of superoxide dismutase in the human ovary Human Reproduction 6 1349-1353

Slater TF (1984) Free radical mechanisms in tissue injury Biochemical Journal 222 1-15

Sugino N, Tamura H, Nakamura Y, Ueda K and Kato H (1991) Different mechanisms for the inhibition of progesterone secretion by ACTH and corticosterone in pregnant rats Joumal of Endocrinology 129 405-410

Tappel AL (1973) Lipid peroxidation damage to cell components Federation Proceedings 32 1870-1881

Tappel AL (1980) Vitamin and selenium protection from in vivo lipid peroxidation Annals of the New York Academy of Sciences 355 18-26 